\title{
Rethinking Potentials of Public Space and its Management Through Placemaking in Kuala Lumpur
}

\author{
Normah Sulaiman ${ }^{1, a}$, Nurul Husna Qamaruz Zaman² Hazlina Hamdani ${ }^{3}$ and Yusfida Ayu Abdullah ${ }^{4}$ \\ ${ }^{1}$ Centre of Postgraduate Studies, Faculty of Architecture, Planning and Surveying, 40450 UiTM Shah Alam, Selangor, Malaysia. \\ ${ }^{2}$ Centre of Studies for Town and Regional Planning, Faculty of Architecture, Planning and Surveying, 40450 UiTM Shah Alam, \\ Selangor, Malaysia. \\ ${ }^{3}$ Centre of Studies for Town and Regional Planning, Faculty of Architecture, Planning and Surveying, 40450 UiTM Shah Alam, \\ Selangor, Malaysia. \\ ${ }^{4}$ Centre of Studies for Town and Regional Planning, Faculty of Architecture, Planning and Surveying, 40450 UiTM Shah Alam, \\ Selangor, Malaysia.
}

\begin{abstract}
Public space takes many spatial forms, including parks, the streets, sidewalks and footpaths that connect an edge of a space between buildings or roadsides, hence are important spaces in an urban setting. In a city context, the public space frames the city image. Kuala Lumpur's public spaces are typically made up of shopping streets. It allows an ambivalent space that encourages more activities and interactions through the continuity of the street. For that reason, street that brings out life and movement in an urban space is an ideal type of street. In maintaining public spaces and reinventing it, placemaking is a quest for engagement tool to help strengthening legal frameworks in order to protect the public space which is seen viable at a city level. This paper therefore, explores the potentials of public spaces and its management. It applies the case study method by means of investigating two areas in the city encompassing similar characteristics. Generally, the research is designed to test the theoretical framework in managing the public space and its key dimensions in shaping the quality of public space. The researcher then synthesizes the broad range of development of placemaking and the changing uses of public space. The findings will advance further understanding of a suitable application thus intensify the legal framework that shapes the quality of space and its management.
\end{abstract}

\section{Introduction}

Public space is vital to a well-functioning city. Public space is where public is free to access anything that relates to build and natural environment. In this space is where unexpected meetings, public gatherings, point of relaxation happen and something by functional, it's an ordinary passage. Generally, it is also an access point of buildings, connectors to nearby places and a strong city's identity.

Management of public space requires the manager with an ability to understand the issues and relates to the purpose of space. It is a set of processes and practices that keeps the public space a fulfilling and functional space besides managing the interaction between the space and the users. Understanding the types and needs of public space is key and it is also a platform to provide good examples of practice in the management where can be exemplary by others. A mutual profit and concerned on improvements in human and environmental is a priority in seeing good management in coordination.

The aim of this study is to provide evidence of a theoretical framework in managing the public space and its key dimensions in shaping the public space quality.
The study will synthesize the broad range development of place making and the changing use of public space. The results from this study will advance further understanding of a suitable application thus strengthening the legal framework that shapes the quality of public space and its management.

This paper is organized into four sections. The subsequent sections with the literature review of the study. The third section provides the methodology, followed by the results and discussion section. The final section offers the conclusion and implications of the results.

\section{Literature Review}

\subsection{The concept of public space}

According to Project for Public Space "Great public spaces are where celebrations are held, social and economic exchanges take place, friends run into each other, and cultures mix" (PPS, 2013) [1]. "Public space relates to all those parts of the built and natural environment where the public have free access"

\footnotetext{
${ }^{\mathrm{a}}$ Corresponding author: normajean.ds@gmail.com
} 
(Carmona et al 2004:10) [2]. Carmona understood that access to public space is free for all and it is related to a physical space. Similarly, Claudio (2010) [3], defines public space as extended to communal and no-private arenas regardless of ownership including semi-public, luminal or third spaces. Norberg (2007) [10], clarifies that space represents the physical container of activities and objects while the place is a point where physiological and psychological needs meet. "Space as a social and political product, space as a product that one buys and sells" as formularize by Lefebvre (1991) [4], explains that space has 'the right to be different', lived and become more humanized. Dear and Wolch (1989) [5], argues that social relations can be constituted through space, constrained by space and mediated by space. They explained that site characteristics influences settlement form, physical environment facilitates or obstruct human activity and the frictions of distance facilitates or inhibit is the development of various social practices. This argument shows that physical factor is neither the exclusive nor dominating behaviour influence although one tends to follow what the environment offers them.

\subsection{Placemaking}

Placemaking is a community approached planning and managing public spaces. "Building community, creating places, using common sense" is the vision of Project for Public Space (PPS) [1]. Places cannot be designed like land marks, however, placemaking focuses on creating spaces that recognize landscapes as part of social constructions that promotes livability, health and wellbeing. Friedmann (2010) [6], refers to physical spaces that evolve in their own pattern and rhythms of life as a place. The state may control the physical context for activities within a certain time which permits certain public behavior and which is not.

Pioneering in the placemaking approach based on extensive research and projects involvement, PPS finds that a successful place must have four key attributes like accessible, people engaged in activities, comfort and sociable place for people to interact. These key attributes are intangibles qualities required for a high-quality environment based on their analysis of hundreds of public spaces around the world. PPS developed the place diagram which is used as measuring tools to evaluate the value and potentials of a place through its tangible and intangibles qualities. Almost all writers, researchers and urban planners present their literature dealing with desirable qualities of public space. Lynch (1979) [7], simplified five desirable qualities in public space such as control, fit, sense, vitality and access.

Shinjuku Station, Tokyo is listed as great public spaces by Project for Public Spaces using the place diagram framework. Entrances to and fro the station is open to all streets and connected radially from it to many parts of the downtown where trains are connected to the whole city. Shinjuku station is connected and accessible from all streets with easy navigation within and towards as well as with choices of activities and there are no dead spaces in this station. Even during peak hour, Shinjuku
Station is very clean and comfortable to be utilized. Besides safe, Shinjuku is the most common meeting placemaking it the most sociable place to be with easy access and trains passing from all parts of the city (PPS, 2013) [1].

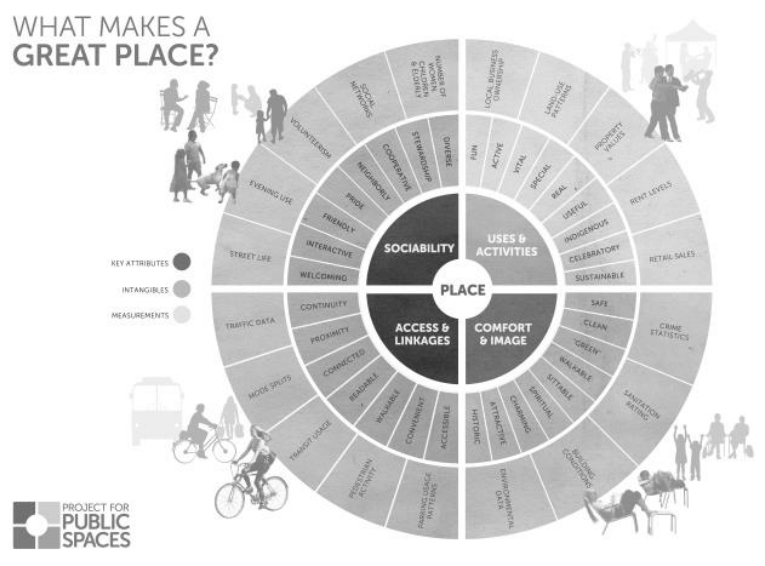

Figure 1. Place-diagram of what makes a great place by PPS. Source: PPS (2013), [1].

\section{Methodology}

\subsection{Case Study}

Case studies on local urban areas will be the substructure of the subject matter highlighted. These areas are selected based on the similar activities within the district, its usage and activities and its adjacent location. The area inside the building functions as private in nature is not included in the scope of the study. This is an indicator that the study only encircles the relationship, value and input of public space and its management dimensions. The rationale of selecting the case studies is to initiate preliminary experimental subject to bigger scope that can be developed further in the future.

Streets in an urban context are places of economic and social significance. An urban fabric that remains longer then the people whose' live constructed through streets and block structures of development. Spaces in the East and the West induce different uses of spaces. Kurokawa (1994) [8], philosophy's states "street spaces exist between private and public space and between residential and commercial space, possessing the characteristics of both the former and the latter types of space. Asian street, by contrast, is not so clearly defined, it is harder to tell where it begins or ends, and it generates responses to innumerable variations with time. Malaysia's early settlements begin with 'main streets' that activities foster social interactions within crowds engaging with selling and buying activities (Shamsuddin and Ujang, 2008) [9].

\subsubsection{Jalan Tuanku Abdul Rahman (Jalan TAR)}

An area that has a strong sense of character with heritage buildings, contemporary architecture and preserved 
facades, this area is famously known with the Malay community commercial and trading area. Evolving with the urbanization, Jalan TAR is developed as commercial vicinity that also represents the Kuala Lumpur old city centre with the core function of this road is retail offering a variety of consumer goods. This street consists of office, shopping malls, arcades, hotels and restaurants.

\subsubsection{Jalan Bukit Bintang (Jalan BB)}

Jalan BB is known as the premier shopping street, comprehensive shopping and entertainment development. This beating heart of the city consists of the promenade of restaurants, cafes, malls and acted as the main commercial hub within the golden triangle. By the year 2020 , this area will be a commercial and premier tourist precinct.

\subsection{Data collection}

This study uses questionnaires to gain data from the public for both case study areas. The questionnaire is divided into five sections; structured and organized using the place diagram intangibles variables. Convenience sampling technique is applied and is useful in documenting the quality of phenomenon of the study which allows the researcher to obtain basic data and trends within case study areas. The target population within the area can be accessed easily and conveniently and sample size for each area was not less than 100 respondents.

The second part of data collected for this research was via interviewing the key people in Kuala Lumpur City Hall, The Town and Country Department and National Landscape Department. The data collection was completed in 14 days. The key people various local government agency was selected based on their experience, knowledge and position in the department. The researcher presented the open-ended question to each personnel.

\section{Results and discussion}

Core components of urban design relate to the understanding of the relationship between people or society and their environment where human behavior is influenced by the physical environment actively and changing the environment as it influences and changes them too. It thus can be seen as a two-way process of creating and modifying spaces while at the same time influenced by those spaces. The place diagram tool was used to evaluate both physical condition (Table 1) and user experience (Table 2) of the two shopping streets using the key and intangible attributes of the place.
Table 1. Physical conditions findings for shopping streets

\begin{tabular}{|c|c|c|c|}
\hline $\begin{array}{l}\text { Intangibles } \\
\text { Attributes }\end{array}$ & Components & $\begin{array}{c}\text { Jalan } \\
\text { TAR } \\
(\mathrm{N}=100)\end{array}$ & $\begin{array}{l}\text { Jalan BB } \\
(\mathrm{N}=100)\end{array}$ \\
\hline $\begin{array}{l}\text { Access and } \\
\text { Linkage \& }\end{array}$ & $\begin{array}{l}\text { Condition of } \\
\text { sidewalk }\end{array}$ & \multicolumn{2}{|c|}{ Satisfactory } \\
\hline \multirow[t]{3}{*}{$\begin{array}{c}\text { Comfort } \\
\text { and Images }\end{array}$} & $\begin{array}{l}\text { Sidewalk } \\
\text { clearly } \\
\text { define }\end{array}$ & \multicolumn{2}{|c|}{ Very Good } \\
\hline & $\begin{array}{c}\text { Enough } \\
\text { room to walk }\end{array}$ & \multicolumn{2}{|c|}{ Good } \\
\hline & $\begin{array}{l}\text { Condition of } \\
\text { streets }\end{array}$ & \multicolumn{2}{|c|}{ Satisfactory } \\
\hline \multirow[t]{2}{*}{$\begin{array}{l}\text { Uses and } \\
\text { Activity : } \\
\text { Uniqueness }\end{array}$} & $\begin{array}{c}\text { Space is } \\
\text { suitable for } \\
\text { public } \\
\text { performance } \\
\text { (i.e. :flash } \\
\text { mobs) }\end{array}$ & \multicolumn{2}{|c|}{ Good } \\
\hline & $\begin{array}{c}\text { Space } \\
\text { appears } \\
\text { special }\end{array}$ & \multicolumn{2}{|c|}{ Satisfactory } \\
\hline $\begin{array}{l}\text { Sociability } \\
\text { : Diversity }\end{array}$ & $\begin{array}{c}\text { Space is } \\
\text { favorable for } \\
\text { celebration }\end{array}$ & \multicolumn{2}{|c|}{ Satisfactory } \\
\hline $\begin{array}{r}\text { Respor } \\
3=\mathrm{Sa}\end{array}$ & $\begin{array}{l}\text { format : } 1= \\
\text { factory, } 4=\mathrm{G}\end{array}$ & $\begin{array}{l}\text { y Poor, } 2 \\
5=\text { Very }\end{array}$ & $\begin{array}{l}\text { Poor, } \\
\text { ood }\end{array}$ \\
\hline
\end{tabular}

Table 2. User experience findings on shopping streets.

\begin{tabular}{|c|c|c|c|}
\hline $\begin{array}{c}\text { Intangibles } \\
\text { Attributes }\end{array}$ & Components & $\begin{array}{c}\text { Jalan } \\
\text { TAR } \\
(\mathrm{N}=100)\end{array}$ & $\begin{array}{c}\text { Jalan BB } \\
(\mathrm{N}=100)\end{array}$ \\
\hline $\begin{array}{c}\text { Access and } \\
\text { Linkage : } \\
\text { Walkability }\end{array}$ & $\begin{array}{c}\text { Pleasant } \\
\text { walk }\end{array}$ & Neutral \\
\cline { 2 - 4 } & $\begin{array}{c}\text { Continue } \\
\text { walking } \\
\text { despite } \\
\text { weather }\end{array}$ & Neutral \\
\hline $\begin{array}{c}\text { Uses and } \\
\text { Activity : }\end{array}$ & $\begin{array}{c}\text { Welcoming } \\
\text { feeling }\end{array}$ & \multicolumn{2}{|c|}{ Neutral } \\
\cline { 2 - 4 } & $\begin{array}{c}\text { Enjoying } \\
\text { public art } \\
\text { features }\end{array}$ & \multicolumn{2}{|c|}{ Neutral } \\
\cline { 2 - 4 } & $\begin{array}{c}\text { Return to the } \\
\text { place again }\end{array}$ & \multicolumn{2}{|c|}{ Neutral } \\
\hline
\end{tabular}




\begin{tabular}{|c|c|c|c|}
\hline \multirow[t]{3}{*}{$\begin{array}{l}\text { Sociability } \\
\text { : Diversity }\end{array}$} & $\begin{array}{c}\text { Allows } \\
\text { social } \\
\text { interaction }\end{array}$ & \multicolumn{2}{|c|}{ Neutral } \\
\hline & $\begin{array}{c}\text { Takes } \\
\text { picture } \\
\text { around the } \\
\text { place }\end{array}$ & \multicolumn{2}{|c|}{ Neutral } \\
\hline & $\begin{array}{l}\text { Chit chatting } \\
\text { at the place }\end{array}$ & \multicolumn{2}{|c|}{ Very Likely } \\
\hline \multirow{2}{*}{$\begin{array}{c}\text { Comfort } \\
\text { and Images } \\
: \\
\text { Cleanliness }\end{array}$} & Any Litter & \multicolumn{2}{|c|}{ Neutral } \\
\hline & $\begin{array}{l}\text { Graffiti on } \\
\text { the streets }\end{array}$ & Neutral & Unlikely \\
\hline $\begin{array}{r}\text { Respon } \\
3=\text { Neutra }\end{array}$ & $\begin{array}{l}\text { ormat: } 1=\mathrm{N} \\
=\text { Very Likel }\end{array}$ & $\begin{array}{l}t \text { all }, 2= \\
=\text { Extre }\end{array}$ & $\begin{array}{l}\text { ikely, } \\
\text { Likely }\end{array}$ \\
\hline
\end{tabular}

\subsection{The Place-diagram intangibles attributes.}

\subsubsection{Walkability}

The physical condition of the place shows that in both study areas the sidewalks is provided clearly for users to use and in satisfactory conditions for walking. This is meaningful to indicate that sidewalks in both areas are comfortable enough to link users to the adjacent places. The response indicates that the sidewalks in both areas are comfort enough to accommodate high numbers of users without clashes. Results also show that there are distinguish significance in walking experience for users which appear to be only satisfactory and does not offer more experience that just walking.

In both study area, it is understood that space is well connected and easily access. Users in both areas find walking is convenient and the scene activities surrounding the context constantly changing and it offer shorter trips to most places. Users will still continue walking despite the weather affecting the areas which implies that this space is easy to walk. This clearly shows that the study illustrates that the street is functional and act as a mode of movement for users. Still, the study also indicates that small group of users walking experience appears to be very unpleasant.

\subsubsection{Uniqueness and Special}

For key attributes uses and activities, the study evaluates the uniqueness and special level within both areas of the research. The response for this question proves that both study areas appear to be lively with activities and distinctive in its own way. Although the core activities are similar, Jalan Bukit Bintang offers more participation and activities for users to keep as memories. Indirectly, it gives Jalan Bukit Bintang a stronger sense of place and special in the eyes of the users. The users enjoy the character of this street and everyday life that takes place in between the buildings and its atmosphere. In both study area, the activity pattern appears to be very significance with its sense of place that exist perhaps for many years and still intact with the surrounding despite changes taken place. People are seen interacting with one another even in small pocket space and enjoying their walk to connecting places.

\subsubsection{Friendliness and Diversity}

For key attribute of sociability, the researcher measured the friendly and diverse variable within both research areas. The response for these variables indicates that users in both areas include themselves in passive and active activities such as listening, chatting, singing and profiling people. Activities as such can be seen done in a small and medium group or even individually in both areas. The results are also meaningful when users return to the same place to be participating in activities in this area with friends, a family with a happy smile and proud feeling. The reaction of users in both areas indicates both study area is a good place to be. The second set of the results implicates that space is favorable for public gatherings such as celebration. An optional activity is a new attraction to places especially for Jalan Bukit Bintang, where the urban culture is more prominent and the quality of it appears to be high as well.

\subsection{Management of public space.}

\subsubsection{Jalan TAR}

The interview findings will help the study to look at the potentials of public space from the management perspective, formulated based on the findings of key attributes that were used in the questionnaires. From the interview, it was discovered that the management suggested that having more shaded areas physically, providing interactive landscape elements and more public realms will help to enhance the walking experience. Suggestion includes, to creatively implements landscape psychology in public spaces to improve the area. The management perceives the user experience in the place as normal behavior as space is apparent to be functional and does not offer more towards users, hence it was a satisfactory.

The sense of place was seen as an important factor from the management perspective because Jalan Tuanku Abdul Rahman is a focal point with good transportation connection for tourist's attraction. The activity pattern in this area was the main reason for users to come to this area. The commercial activities have been around for years offering a comfortable feeling to users who want the pattern of activities to continue and feel safe doing it. The interview responses clearly indicate that the cleanliness of this area is maintained by the authority that ensures the place is kept clean with no damages. They also suggested that the government should privatize the area to make it better by adding elements that can be 
easily maintained and sustainable so as to blend well with the surrounding context.

\subsubsection{Jalan $B B$}

From the interview, it was determined that there were more pocket spaces for public in the area. The management feels that the spaces are spacious and comfortable for users hence more creative solutions must be implemented in improving users' experience by creating more activities and events. This area is privately managed and operated. The feedback from the general public relate to the design process of space which was functional for users and private sector or provider. It was suggested as well that space lacks of unique landscape elements and the manipulation of landscape psychology which users can add to their normal daily routine, therefore changing their routine into a more exciting experience. The private sector must therefore keep the area interesting, clean and well manage.

The sense of place here differs from Bukit Bintang, whereby Bukit Bintang, a highly concentrated urban area attracts chic modern urbanites with clean and interesting atmosphere besides being popular shopping street. Any upcoming elements complement the idea of an urban area, and should be strategically placed so as not to clutter the tight space. The interview prompted the management that activity pattern here is very favorable by many with different quality and more diverse. Management believes that the owner or private sector has to be creative to create activities to attract more visitors. In achieving a successful public space, the interview finds that the authority and everyone plays an important role. Form and function are an important application to attract visitor to utilize space, be it local and foreign, at the same time space must be maintained by authorities, comfortable enough for users to carry out daily activities and appreciated by them. The survey also revealed that this perhaps can be a joint venture effort or privatized to achieve certain objective and purpose.

\section{Conclusion}

From the study, it is found that there is no proper management framework for public space. The place diagram is used as a tool to synthesize the broad range of development of placemaking and the changing use of public space. This paper addresses the potentials of public space and its management lies in the intangibles qualities of the diagram. In managing existing public space, a dynamic collaborative effort by all is vital. From this research, it unleashes the potentials of public space which focuses on the end users. Here, management gives the rights to the public to use, access and owned or control the space according to as the definition permits. Results of this research suggest scholars and professionals to explore key attributes of placemaking strategies using the place-diagram as a tool in the future.

\section{Acknowledgements}

The authors would like to thank the Malaysia's Ministry of Higher Education for funding the study through a RAGS grant with the project code $600-\mathrm{RMI} / \mathrm{RAGS} 5 / 3$ (170/2013) and also would like to thank the Universiti Teknologi MARA (UiTM), specifically, the Research Management Centre (RMC) for supporting and managing this grant.

\section{References}

1. PPS (2013). Project for Public Spaces | Placemaking for Communities [online] Available at http://www.pps.org [Accessed: 26 April 2013]

2 Carmona, M., MagalhãES, C. D., \& Hammond, L. (2008). Public space: the management dimension. London, Routledge.

3. Claudio De Magalhães (2010). Public Space and the Contracting-out of Publicness: A Framework for Analysis, Journal of Urban Design, 15:4, 559-574.

4. Lefebvre, H. (1991). The production of space, trans. Donald Nicholson-Smith (1974, 282).

5. Dear, M., \& Wolch, J. (1989). How territory shapes social life. The power of Geography, 3-18.

6. Friedmann, J. (2010). Place and Place making in Cities: A Global Perspective. Planning Theory \& Practice, 11(2), 149-165. http://dx.doi.org/10.1080/14649351003759573

7. Lynch, K. (1979). The image of the city. 1960. Cambridge, MA.

8. Kurokawa, K., \& Kurokawa, K. (1994). The philosophy of symbiosis. Academy Editions.

9. Shamsuddin,S., and Ujang, N.(2008). Making places: The role of attachment in creating the sense of place for traditional streets in Malaysia. Habitat International, 32(3), 399-409. http://dx.doi.org/10.1016/j.habitatint.2008.01.004

10. Carmona, M. (2010). Public places, urban spaces: the dimensions of urban design. Oxford, UK, Architectural Press.

11. Matthew Carmona (2010). Contemporary Public Space, Part Two: Classification,Journal of Urban Design, 15:2, 157-173.

12. May, T. (2013). The Urban Everyday: The History and Dynamics of Place Making. Symbolic Interaction, 36(2), 234-236. http://dx.doi.org/10.1002/symb.57 